\title{
THE QUALITY OF INCLUSIVE EDUCATION FROM THE PERSPECTIVE OF TEACHERS IN POLAND AND CROATIA
}

\author{
ANAMARIJA ŽIC RALIĆ ${ }^{1}$, DANIELA CVITKOVIĆ ${ }^{1}$, AGNIESZKA ŻYTA ${ }^{2}$, KATARZYNA \\ ĆWIRYNKALO ${ }^{2}$ \\ ${ }^{1}$ Faculty of Education and Rehabilitation Sciences, University of Zagreb, Croatia, contact: anamarija.zic.ralic@erf.hr \\ ${ }^{2}$ University of Warmia and Mazury in Olsztyn, Poland
}

Received:13.09.2019.

Original research article

Accepted: 14.09 .2020 .

UDK: 37-051(438)(497.5):376

doi: $10.31299 /$ hrri.56.2.6

\begin{abstract}
The aim of the study was to explore Croatian and Polish teachers'opinions on quality of inclusive education. A sample of 173 teachers from Poland and 139 from Croatia completed the Scale on Quality Indicators for Inclusion-for Teachers. In general, teachers reported positive assessments of inclusion quality. Respondents from both countries gave highest ratings on the subscale Support monitoring and evaluation, while the lowest ratings were given on the subscale Teaching assistant support by Polish participants and on the subscale Resources for inclusive education by the Croatian sample. Poland teachers gave higher ratings than Croatian teachers on all the subscales except Teaching assistant support. The discussion makes an attempt to present how two different societal contexts shape the development and implementation of inclusion.
\end{abstract}

Key words: inclusive education, quality, teachers, special education needs

\section{INTRODUCTION}

The provision of high-quality, inclusive education for all children regardless of their abilities and disabilities has been perceived as an essential goal in initiatives and legislation for a long time (UNESCO 1994). Despite a wide variety of the proportion of students with special education needs in mainstream education in European countries, a strong international trend towards inclusion can be observed (Winter, O'Raw 2010; Soriano, Watkins and Ebersold, 2017; Ferguson, 2008). Currently, the focus is on school practices and supports that ensure high-quality education that would guarantee academic achievements and behavioural progress for all students.

For the purpose of this study, the theory of Ainscow, Booth, and Dyson (2006) was used, according to which inclusion can be perceived in three overlapping ways: as reducing barriers to learning and participation for all students, as increasing the capacity of schools to respond to the diversity of students in their local communities in ways that treat them all equally, and as putting inclusive values into action in education and society. Moreover, inclusion is understood as a multidimensional concept which contributes to full respect for human rights, social justice and provides equal opportunities to all, affirming the social model of approach to differences (Hornby, 2014).

Research findings suggest that inclusion may take various forms depending on the contexts but despite these differences, there is a substantial agreement regarding the key practices which support the implementation of inclusion (Lindsay 2003; Winter and O'Raw, 2010). Based on the literature review, the indicators include: welcoming and supportive school / class climate, curriculum adaptations, refocused use of instructions and assessment, programme planning and Individual Education Plan (IEP) development, appropriate programme implementation, peer interactions, individual student support, appropriate funding levels, family-school partnership and parental involvement, collaborative planning and teaching, and professional development (Booth and Ainscow 2002; Winter and O'Raw 2010; Ivančić 
2012; Loreman 2013; Forlin et al. 2013; Carter et al. 2016, Saloviita and Schaffus 2016). The analysis of studies on inclusion indicates that the move to support inclusive practices at schools should be supported by all stakeholders: people responsible for educational policy (Fernandez-Batanero and El Homrani 2016), teachers (Ćwirynkało et al. 2017, Saloviita and Schaffus 2016), children (Adderley et al. 2015, Carter et al. 2016) and their parents.

For the purpose of this study, Ivančić's (2012) model of indicators of quality of inclusive education was used. This model is based on the concept of inclusive education as a reform that supports and welcomes diversity amongst all learners (UNESCO, 2001). This model is based on existing knowledge about inclusive education and Ainscow, Booth, and Dyson's theory (2006). Based on the theory, the tool 'Index for inclusion' was created with the purpose to improve schools according to inclusive values. The 'Index for Inclusion' (Booth and Ainscow 2002) focuses attention on three dimensions of school life, i.e. practices, policies and cultures and, as other studies prove, provides a research-based agenda that can be used to plan, guide and monitor action research activities in schools and classrooms (Ainscow, Booth, Dyson 2006). Ivančić's model of indicators of quality of inclusive education (Ivančić, 2012) consists of six indicators: Inclusive ethos of the school, Curriculum focused on students, Differentiated teaching and learning, Support in monitoring and evaluation, Teaching assistant support and Resources for inclusive education. The inclusive ethos of the school reflects willingness for education of ALL, reflects the atmosphere of tolerance and acceptance of diversity, and applies to all subjects in school, including school professionals, students, parents and other staff (Ivančić, 2012). This is one of the key areas in inclusive education (Lausselet, 2005). Ivančić (2012) points to the importance of such a curriculum that enables effective teaching all students with support in monitoring and evaluation. This model emphasises differentiated teaching and learning that includes IEP as well as teaching assistant support and professional team support. The team-based collaboration of teachers and related personnel support becomes more important when the number of students with disabilities in development that is integrated into general education increases (Gallagher, Malone, Lander, 2009). Resources for inclusive education include removing obstacles and providing material equipment for all students, as well as competency of all school staff for inclusion (Ivančić, 2012).

\section{Background}

In this work, we compare teacher's perspective on the quality of inclusive education in Croatia and Poland, European countries with certain similarities and differences in the approach towards inclusive education. The two states belong to the block of post-communist European countries in which students with disabilities were often marginalised and institutionalised. However, both countries became European Union members (Poland since 2004, Croatia since 2013) and ratified the Convention on the Rights of Persons with Disabilities (Croatia - in 2007, Poland - in 2012), which influenced the educational policy towards disadvantaged groups of children. Furthermore, both Poland and Croatia have a relatively long history of implementing integration/inclusion in education (the right of students with disabilities to learn in mainstream schools was legalised in 1980 in Croatia and in 1991 in Poland). In Croatia, there is a tendency to place the children in mainstream education, but children with severe disabilities more often attend special education schools. In the Polish educational system, it is the right of parents to decide whether their child with special education needs will be educated in a segregated, integrative or inclusive form of education (Chrzanowska 2015). Despite satisfactory legal regulations in both countries, the process of providing all learners with equal educational opportunities is still considered a challenge. The main problems of inclusive education in Croatia and Poland are the lack of specialists in schools, insufficient amount of didactic aids for children with special education needs, architectural barriers, lack of professional education and rehabilitation support, (in)competence and work overload of teachers as well as not always positive attitudes towards inclusion of children with special education needs (Žic Ralić 2012; Kranjčec Mlinarić et.al. 2016; Ciechanowski et al. 2010; Ćwirynkało, 2013). Although some studies (e.g. Ćwirynkało and 
Żyta 2015; Žic Ralić, 2012) indicate that there have been a number of positive changes in the past several years, many schools still lack solutions and an atmosphere that could be called fully inclusive.

\section{Teacher's perception of educational inclusion}

Most previous research related to the inclusion have examined the attitudes of teachers towards students with disabilities, attitudes toward inclusion and willingness and readiness to work in inclusive conditions (De Boer, Pijl, Minnaert, 2011). Teachers with more positive attitudes towards inclusion were more likely to adapt their classroom learning environment to meet the needs of a range of students (Ryan, 2009; De Boer, Pij1, Minnaert, 2011). In these classroom environments there are greater levels of satisfaction and cohesiveness and lower levels of friction, competitiveness and difficulty than in the ones with teachers who held less positive attitudes (Monsen, Ewing, \& Kwoka, 2014).

Research shows that Croatian teachers have a generally positive attitude towards inclusion, they are ready to accept students with disabilities, they have a tolerant approach and respect children's rights, and they understand the positive effect of inclusion on the social development of students with disabilities, but also on other students (Martan, 2018; Ljubić \& Kiš-Glavaš, 2003; Bouillet, 2013; Kranjčec Mlinarić, Žic Ralić \& Lisak, 2016; Skočić Mihić, Gabrić \& Bošković, 2016). However, teachers also show a certain degree of indecision in their attitudes and provide conditional support to inclusive education, emphasising insufficient school readiness to implement inclusion, concerns about the impact of student disability on teacher's management of the classroom, as well as unwillingness to take full responsibility to teach students with disabilities (Bouillet, 2013; Bouillet \& Bukvić, 2015; Martan, 2018). Croatian teachers are more likely to teach students with milder difficulties than those with more complex educational needs, which reflects their insecurity, unpreparedness and insufficient knowledge of the peculiarities and student needs as well as lack of professional support (Martan, 2018). According to Čepić, Tatalović Vorkapić, Lončarić, Anđić, Skočić Mihić, Kalin, and Šteh (2017), Croatian teachers, similarly to Slovenian teachers, assess themselves as qualified for inclusive education using advice from support staff, for the application of individualised procedures, cooperation and creating classroom environment through strengthening students' social skills and positive class discipline. According to Kudek Mirošević and Jurčević Lozančić (2014), Croatian teachers find that they lack adequate knowledge for working with students with developmental disabilities in general, and that existing professional development that is offered is not sufficiently practical.

Croatian authors Nikčević-Milković, Jurković and Durdov (2019) have found mostly positive perception of the implementation of inclusion by teachers in Lika-Senj County. The majority of teachers in the sample did not have courses on teaching students with disabilities during their pre-service teacher training. Nevertheless, teachers with less training for teaching students with special education needs, but with greater support from schools, have more positive estimates of their teaching methodology and are more likely to apply individualised programmes, attend professional development and establish cooperation. Perception of inclusion is more positive if there are fewer students with special education needs per class, teachers are younger and if subject teachers have humanities and social studies profiles.

Polish studies conducted among teachers indicate that they have a positive attitude towards integration and inclusion (Barańska \& Sirak, 2015; Domagała-Zyśk, 2018) and see benefits of inclusion for both children with disabilities (Bartnikowska, Ćwirynkało \& Żyta, 2016) and typically developing children (Bartnikowska, Ćwirynkało \& Żyta, 2016). Teachers present a high level of acceptance for inclusion in case of students with milder forms of disability: hearing and visual impairment as well as mild intellectual disability (Ćwirynkało \& Żyta, 2015; Uberman \& Mach, 2016). The level of acceptance for the presence of students who are blind, deaf or with deep intellectual disabilities in the integration and public schools is definitely lower (Ćwirynkało \& Żyta, 2015; Bąbka \& Podgruszewska, 2016; Uberman \& Mach, 2016). Teachers also report concerns about their own competences to support students with special education needs: they see the need to train and improve their own skills (Bartnikowska, Ćwirynkało \& Żyta, 
2016; Bąbka \& Podgruszewska, 2016; Skotnicka, 2016; Uberman \& Mach, 2016).

Several papers have dealt with the perception of quality of inclusion using adaptation of the Index for inclusion. Braunsteiner and Mariano-Lapidus (2017) investigated the perceptions of, and attitudes toward, inclusive schooling in teacher and administrative candidates in the USA and Austria using items derived from the Index for Inclusion (Booth and Ainscow, 2011). Responses were analysed in terms of differences between institutions, past experience and certification area. Participants from both institutions reported statistically high levels of support for inclusive education, with the US participants also reporting statistically high levels for self-efficacy in implementing inclusive practices. However, the majority of candidates from both institutions (58\% for the USA and 64\% for Austria) stated that inclusion was not always appropriate.

In Spain, an adaptation of the Index for Inclusion was applied to a large sample of 430 families, teachers, and managers (Sánchez Rodríguez Sandoval, 2019). In this paper the authors analysed the discrepancy between the highest results related to some indicators, such as high expectations for all the students and inclusive viewpoint proposed by the management team, and the worst results, which related to issues which have traditionally been a barrier to educational quality and inclusion. They also discussed the formulation of some questions which implied socially desirable answers.

In these studies the length of teaching in inclusive settings was not examined. Teaching experience in inclusive school has an impact on teaching attitudes (Moberg 2003), therefore we would propose that it could reflect correlation between the length of teaching and assessment of quality of inclusion.

\section{Purpose of the study}

Very few papers have examined the perception of the quality of inclusion by teachers. The purpose of this study is to contribute to insights into teachers' subjective estimation of the quality of inclusion in two European countries. The study is focused on teacher's estimation because they are important bearers of inclusive process, daily engaged in realisation of inclusive education. Therefore, it is important to find how teachers assess the quality of inclusion, in which areas they feel that there is room for improvement, and where they see barriers to inclusion. Their assessment of the quality of their own work and the work of the school due to the inclusion of indicators is important also because it can boost self-reflection and thus affect their future inclusive teaching practice (Zeichner, \& Liston, 1987).

The paper is an outcome of the research project "Quality of inclusion indicators from the perspective of Croatian and Polish education teachers", which was carried out by the team members from two universities: the University of Zagreb in the Republic of Croatia and the University of Warmia and Mazury in Olsztyn, the Republic of Poland (2016-2018). The research was based on the Booth and Ainscow model of inclusion. The aim of the study was to explore and compare Croatian and Polish teachers' opinions on quality of inclusive education.

Three research questions were created:

1. How do Polish and Croatian teachers estimate the quality of inclusion, taking into account the following indicators: inclusive ethos of the school, curriculum focused on students, differentiated learning and teaching, teaching assistant support, resources for inclusive education, support monitoring?

2. Are there any statistically significant differences between teachers' opinions on quality indicators for inclusive education in Poland and Croatia?

3. Are there statistically significant differences in assessments of inclusion quality regarding the teachers' length of service?

\section{METHOD}

In order to answer the research questions, a diagnostic survey method was used. The research was embedded in the quantitative research paradigm.

\section{Measuring Instruments}

Participants were asked to complete the General questionnaire for teachers, which consisted of questions about age, gender, and working experience.

The Scale on Quality Indicators for Inclusion - for Teachers (Ivančić, 2012) was used to measure 
the quality of inclusive education in primary schools in Croatia and Poland. The Scale was created by Ivančić and Stančić (Ivančić, 2012) on the basic of inclusive practice, questionnaires for self-evaluation of school quality in Croatia (Bezinović, 2010) and questionnaires represented in the Index for Inclusion (Booth et. al. 2000; Booth \& Ainscow, 2002). The Scale was translated from Croatian into Polish forward and backward in order to avoid differences in meaning between the Croatian and Polish versions of the scale. The instrument consists of six subscales: Inclusive ethos of the school (28 items; example: "Regardless of their mutual differences, students of this school feel they are accepted at the school"), Curriculum focused on students (7 items; example: "The curriculum meets the diverse educational needs of our students"), Differentiated teaching and learning (25 items; example: "Teachers use the teaching methods best suited to the needs of individual students"), Support in monitoring and evaluation (21 items; example: "Teachers regularly keep records of the work and progress of all their students"), Teaching assistant support (5 items; example: "In this school, students have a teaching assistant when necessary") and Resources for inclusive education (26 items; example: "Our school has specific equipment for students with disabilities") (Ivančić, 2012). Items are rated on a 5-point Likert-type scale; each item receives a score between one to five: strongly agree (1), generally agree (2), I cannot decide (3), generally disagree (4) or strongly disagree (5). The teacher should choose the statement that best fits the real situation in the school. A lower score indicates a higher quality of inclusion (Ivančić, 2012). Both Croatian and Polish versions of the Scale on Quality Indicators for Inclusion - for Teachers showed good reliability (Cronbach alpha was 0.96 for the Croatian scale and 0.95 for the Polish scale).

\section{Participants, Setting and Procedure}

The sample consisted of teachers ( $\mathrm{N}=139$ from Croatia; $\mathrm{N}=173$ from Poland) in charge of students in the second grade of primary school, amongst whom at least one student had special education needs. The study took place in the school year 2016/2017 and involved 99 schools (out of 166 invited to participate in the research) from Croatia (two districts: Zagreb and Zagreb County) and 47 schools (out of 60 invited to participate in the research) from Poland (three voivodeships: Kuyavian-Pomeranian, Warmian-Masurian and Podlaskie). There is no reason to expect that the quality of inclusive education in these regions in Croatia and Poland is different from the quality of inclusive education throughout the country.

The following sampling criteria were taken into account:

- working in a mainstream primary school;

- being an in-service teacher in charge of second grade students amongst whom at least one had special education needs;

- in Poland: residence in one of the selected voivodeships (Kuyavian-Pomeranian, WarmianMasurian and Podlaskie); in Croatia: residence in one of two Croatian districts (Zagreb or Zagreb County);

- giving consent to participate in research.

The vast majority of participants in both countries were female (Croatia - 94.2\%; Poland $98.3 \%$ ). Such a distribution is an adequate gender balance since at early education level there is a significant proportion of women teachers in the two countries.

Table 1 presents the age and work experience of the sample. There were no statistically significant differences in age and length of service between Croatian and Polish teachers.

\section{RESULTS}

Referring to Research question number 1 (How do Polish and Croatian teachers rate the quality of inclusion?), our interest was focused on how Polish and Croatian teachers rate the quality of

Table 1. Sample of teachers - descriptive data

\begin{tabular}{|l|l|l|l|l|l|l|l|l|l|l|}
\hline & \multicolumn{4}{|c|}{ Gender } & \multicolumn{4}{c|}{ Age } & \multicolumn{4}{c|}{ Length of service (in years) } \\
\hline & Male & female & Min & max & M & Std.Dev. & Min & max & M & Std.Dev. \\
\hline Poland & 3 & 170 & 24 & 60 & 45.5 & 8.17 & 0.40 & 38 & 22.3 & 9.10 \\
\hline Croatia & 5 & 131 & 26 & 60 & 44.8 & 9.10 & 1 & 38 & 20.7 & 10.63 \\
\hline
\end{tabular}


inclusion in their schools. We took into account the following indicators of the quality: Inclusive ethos of the school, Curriculum focused on students, Differentiated learning and teaching, Teaching assistant support, Resources for inclusive education, Support monitoring.

In Table 2 are results of descriptive statistics regarding the first research question.

Distributions of results on all subscales for both countries (except normal distribution of Resources for inclusive education for Croatia) were leftskewed distributions, meaning that majority of teachers positively assessed inclusion quality.

Both Croatian and Polish teachers gave highest ratings on the subscale Support monitoring and evaluation. The teachers positively assessed the way of checking knowledge acquired by students during lessons. They believe that their students receive useful instructions that take into account their specific needs and that students are properly supported during tests. The high assessment also applies to cooperation with parents in the area of monitoring students' knowledge. Teachers from both countries highly appreciate both the level of advice given at school to students regarding the directions for further education, as well as the parents' access to information about the elements they have for further education of their child, which takes into account their knowledge, level of ability and interests.
On the other hand, the lowest ratings were given for Resources for inclusive education in a Croatian sample and for Teaching assistant support in a Polish sample. Resources for inclusive education is related to general school environment, teacher's attitudes toward inclusion, physical barriers for children with disabilities, equipment, teamwork, and cooperation with parents and school professionals. Teachers gave the lowest ratings in the sphere of high-quality school equipment, number of different school professionals, cooperation with parents at the school level and teacher's qualifications for teaching children with disabilities. The subscale Teaching assistant support is related to access to a teaching assistant who is supposed to help in the inclusive educational process, support students with special education needs in academic and social activities in school and help all students in a classroom when necessary.

In order to answer the second research question (Are there any statistically significant differences between teachers' opinions on quality indicators for inclusive education in Poland and Croatia?), a Mann-Whitney U test was done.

As shown in Table 3, the Mann-Whitney U test revealed significant differences between Croatia and Poland in assessment of quality of inclusion on all subscales except Support in monitoring and evaluation. This indicator refers to tracking progress, preparing for the exam, evaluating achieve-

Table 2. Assessments of quality of inclusion - descriptive statistics

\begin{tabular}{|c|c|c|c|c|c|c|c|}
\hline \multicolumn{2}{|l|}{ Country } & $\begin{array}{l}\text { Inclusive } \\
\text { ethos of } \\
\text { the school }\end{array}$ & $\begin{array}{l}\text { Curriculum } \\
\text { focused on } \\
\text { students }\end{array}$ & $\begin{array}{c}\text { Differentiated } \\
\text { learning and } \\
\text { teaching }\end{array}$ & $\begin{array}{c}\text { Support } \\
\text { monitoring } \\
\text { and evaluation }\end{array}$ & $\begin{array}{l}\text { Teaching } \\
\text { assistant } \\
\text { support }\end{array}$ & $\begin{array}{c}\text { Resources } \\
\text { for inclusive } \\
\text { education }\end{array}$ \\
\hline \multirow[t]{6}{*}{ Croatia } & Median & 1.536 & 1.714 & 1.520 & 1.429 & 1.800 & 2,115 \\
\hline & Range & 1.57 & 2.29 & 1.88 & 1.52 & 3.00 & 2,35 \\
\hline & Minimum & 1.04 & 1.00 & 1.00 & 1.00 & 1.00 & 1,00 \\
\hline & Maximum & 2.61 & 3.29 & 2.88 & 2.52 & 4.00 & 3,35 \\
\hline & Kolmogorov smirnov z & $.101 * *$ & $.122 * *$ & $.108 * *$ & $.113 * *$ & $.131 * *$ & ,051 \\
\hline & Skewness & -.700 & -.453 & -.695 & -.796 & -.799 &,- 096 \\
\hline \multirow[t]{6}{*}{ Poland } & Median & 1.464 & 1.571 & 1.400 & 1.333 & 2.200 & 1,769 \\
\hline & Range & 1.82 & 2.14 & 1.44 & 1.62 & 4.00 & 2,27 \\
\hline & Minimum & 1.00 & 1.00 & 1.00 & 1.00 & 1.00 & 1,00 \\
\hline & Maximum & 2.82 & 3.14 & 2.44 & 2.62 & 5.00 & 3,27 \\
\hline & Kolmogorov smirnov $\mathrm{z}$ & $.132 * *$ & $.117 * *$ & $.150 * *$ & $.137 * *$ & $.092 * *$ & , 087 \\
\hline & Skewness & -1.158 & -.519 & -.838 & -.969 & -.641 &,- 488 \\
\hline
\end{tabular}

Note. ${ }^{*} \mathrm{P}<0.05, * * \mathrm{p}<0.01$ 
ments, giving feedback and counseling students and parents about further education.

Polish teachers gave higher ratings on all subscales, except for the subscale Teaching assistant support.

Teachers in Poland rated the following significantly better than Croatian teachers: Inclusive ethos of the school (acceptance and satisfaction of all students, security and support to all students, mutual respect among students, respect for diversity in school, partnership with parents), Curriculum focused on students (appropriate to the different needs of students), Differentiated teaching and learning (assessment of educational needs of students, student-oriented planning, different educational approaches in order to strengthen individual potential), and Resources for inclusive education.

The third research question was to see whether there are differences in estimations of inclusion quality regarding the length of service.

A 2 x 4 ANOVA with country (Croatia, Poland) and length of service as between-subject factors confirmed the results of the Mann-Whitney U test, revealing statistically significant main effects of country on all subscales except Support monitoring: Inclusive ethos of the school $\mathrm{F}(1,302)=3.95$, $\mathrm{p}=0.04$, Curriculum focused on students, $\mathrm{F}(1,302)$ $=5.36, \mathrm{p}=0.02$, Differentiated learning and teaching $\mathrm{F}(1,302)=8.71, \mathrm{p}=0.00$, Support monitoring , $\mathrm{F}(1,302)=0.83, \mathrm{p}=0.36$, Teaching assistant support $\mathrm{F}(1,302)=27.33$, $\mathrm{p}=0.00$; and Resources for inclusive education $\mathrm{F}(1,302)=15.49, \mathrm{p}=0.00$.

There was a significant main effect of length of service only on the subscale Resources for inclusive education $\mathrm{F}(3,302)=2.98, \mathrm{p}=0.03$, while on the other subscales the main effect of length of service was non-significant: Inclusive ethos of the school $\mathrm{F}(3,302)=0.409, \mathrm{p}=0.76$; Curriculum focused on students, $\mathrm{F}(3,302)=0.61, \mathrm{p}=0.61$; Differentiated learning and teaching $\mathrm{F}(3,302)=$ $1.23, \mathrm{p}=0.29$; Support monitoring, $\mathrm{F}(3,302)=0.62$, $\mathrm{p}=.60 ;$ Teaching assistant support $\mathrm{F}(3,302)=$ $0.78, \mathrm{p}=0.51$.

The results therefore indicate that teachers who had been working fewer than 10 years gave better ratings on the subscale Resources for inclusive education than those who had been working for 21-30 years.

The interaction between country and length of service was significant only on Differentiated learning and teaching $\mathrm{F}(3,302)=3.10, \mathrm{p}=0.03$, while there was no interaction between country

Table 3. Differences in estimations of inclusion quality between Croatian and Polish teachers: results of the MannWhitney U test

\begin{tabular}{|c|c|c|c|c|c|c|}
\hline & Country & $\mathbf{N}$ & Mean Rank & Sum of Ranks & $\mathbf{U}$ & $\mathbf{z}$ \\
\hline \multirow{3}{*}{$\begin{array}{l}\text { Inclusive ethos of the } \\
\text { school }\end{array}$} & Croatia & 139 & 173.72 & 24146.50 & & \\
\hline & Poland & 173 & 142.67 & 24681.50 & 9630.500 & $-3.025 * *$ \\
\hline & Total & 312 & & & & \\
\hline \multirow{3}{*}{$\begin{array}{l}\text { Curriculum focused on } \\
\text { students }\end{array}$} & Croatia & 139 & 173.14 & 24066.50 & & \\
\hline & Poland & 173 & 143.13 & 24761.50 & 9710.500 & $-2.933 * *$ \\
\hline & Total & 312 & & & & \\
\hline \multirow{3}{*}{$\begin{array}{l}\text { Differentiated learning and } \\
\text { teaching }\end{array}$} & Croatia & 139 & 173.19 & 24073.00 & 9704.000 & \\
\hline & Poland & 173 & 143.09 & 24755.00 & & $-2.932 * *$ \\
\hline & Total & 312 & & & & \\
\hline \multirow{3}{*}{$\begin{array}{l}\text { Support monitoring and } \\
\text { evaluation }\end{array}$} & Croatia & 139 & 164.13 & 22813.50 & & \\
\hline & Poland & 173 & 150.37 & 26014.50 & 10963.500 & -1.340 \\
\hline & Total & 312 & & & & \\
\hline \multirow[t]{3}{*}{ Teaching assistant support } & Croatia & 139 & 127.63 & 17741.00 & & \\
\hline & Poland & 173 & 179.69 & 31087.00 & 8011.000 & $-5.088^{* *}$ \\
\hline & Total & 312 & & & & \\
\hline \multirow{3}{*}{$\begin{array}{l}\text { Resources for inclusive } \\
\text { education }\end{array}$} & Croatia & 139 & 180.64 & 25109.00 & & \\
\hline & Poland & 173 & 137.10 & 23719.00 & 8668.000 & $-4.238^{* *}$ \\
\hline & Total & 312 & & & & \\
\hline
\end{tabular}


and length of service on other subscales: Inclusive ethos of the school $\mathrm{F}(3,302)=1.49, \mathrm{p}=0.02$; Curriculum focused on students $\mathrm{F}(3,302)=2.07$, $\mathrm{p}=0.10 ;$ Support monitoring $\mathrm{F}(1,302)=1.72, \mathrm{p}=$ 0.16 ; Teaching assistant support $\mathrm{F}(3,302)=0.53$, $\mathrm{p}=0.66$; and Resources for inclusive education $\mathrm{F}$ $(3,302)=2.37, \mathrm{p}=0.07$.

In Croatia the best ratings on the subscale Differentiated learning and teaching were from the group of teachers who had worked 0-10 years (length of service), and the lowest ratings were from the group that had worked 30-40 years. In contrast to Croatia, the best ratings in Poland were from the group that had worked $30-40$ years. The lowest ratings were from the group that had worked 0 -10 years.

\section{DISCUSSION}

The present study allowed us to explore three areas concerning subjective teachers' opinions on the quality of inclusion in Polish and Croatian mainstream school.

First, it describes various indicators of inclusion of children with special education needs.

Generally, we can say that both Polish and Croatian teachers estimate the quality of inclusion positively. This is in accordance with similar studies that indicate positive assessments of work and inclusion by teachers (Żuraw, 2016; Barańska \& Sirak, 2015; Domagała-Zyśk, 2018; Skočić Mihić, Gabrić \& Bošković, 2016; Nikčević-Milković, Jurković, Durdov, 2019), with scores higher in teachers than in case of professionals (Ivančić, 2012) and students (Labus, Miljkovic, 2011).

The results of the current study indicate that teachers from both countries give highest ratings on the subscale Support monitoring and evaluation. The highest ratings on this subscale in both groups of teachers represent a higher level of self-perceived competences regarding monitoring, giving instructions that are tailored to individual needs of their students, checking acquired knowledge and cooperation with parents. These results seem to give more insight into teachers' opinions in Poland, since prior research in this field was inconsistent. On the one hand, Bidziński et al. (2013) have suggested that teachers believe that their professional skills and competences to work with students with disabilities are high. On the other hand, however, there are a number of studies (Bartnikowska et al., 2016; Bąbka \& Podgruszewska, 2016; Skotnicka, 2016; Uberman \& Mach, 2016) in which teachers' concerns about their own competences to support students with special educational needs are emphasised. This result is consistent with the findings of Skočić Mihić (2017) that Croatian teachers perceive themselves as moderately competent for individualised instruction of students from diverse multicultural backgrounds. Although previous research indicated insufficient competencies of Croatian teachers for inclusive education (Bouillet, Domović, Ivančević, 2017; Skočić Mihić et. al, 2014; Bouillet \& Bukvić, 2015), results of the present study show no differences between Polish and Croatian teachers concerning support monitoring and evaluation of teachers' competences. This result also extends existing knowledge gained through other comparative studies, e.g. that of Skoćič Mihić (2017), which indicated no differences between Croatian and Slovenian teachers in implementation of individualised instructions to diverse students.

The analysis of the results of the Polish sample shows that the lowest ratings were on the subscale Teaching assistant support. This result is in accordance with previous studies (Ćwirynkało, 2013; Bidziński et al., 2013) where teachers indicated insufficient numbers of assistants, special educators, psychologists and therapists in Polish mainstream schools.

For the Croatian sample the lowest ratings were given on Resources for inclusive education. This result is in line with one Spanish study (Sánchez Rodríguez Sandoval, 2019) and-numerous Croatian studies (Ivančić, 2012; Nikčević-Milković et al., 2019; Čepić et al., 2017; Kudek Mirošević \& Jurčević Lozančić, 2014; Kranjčec Mlinarić, Žic Ralić, \& Lisak, 2016). Despite changes concerning inclusion quality in a Croatian school system, teachers still emphasise the need for more support from experts in special education needs, e.g. special pedagogues and the need for professional training in this field (Nikčević-Milković et al., 2019; Čepić et al., 2017; Kudek Mirošević \& Jurčević Lozančić, 2014). In a similar study (Kranjčec 
Mlinarić et al., 2016), teachers also mentioned the need for systematic solutions regarding funding as well as removing physical barriers and provision of learning material.

The second area analysed in this study referred to the comparison of Polish and Croatian teachers' assessments of the quality of inclusion. This comparison indicates that teachers from Poland give higher ratings than Croatian teachers of their self-perceived competences for providing inclusive education (represented by curriculum focused on students and differentiated learning and teaching) as well as of perceived inclusiveness on the school level (represented by inclusive ethos of school and resources for inclusive education).

The results concerning significantly better self-perception of Polish teacher's competences for inclusive education that refers to creating a curriculum focused on students, assessment of educational needs of students, student-oriented planning and different educational approaches, could be supported with previous studies that might indicate higher self-perceived competence in Polish than in Croatian teachers. While Polish teachers perceive themselves as highly competent for inclusive education (Bidziński et al. 2013), Croatian teachers are not so positive towards their preparedness for the same challenges (Skočić Mihić, 2017; Bouillet, Domović, Ivančević, 2017; Kranjčec Mlinarić et al., 2016; Bouillet \& Bukvić, 2015; Domović, Vizek Vidović, Bouillet, 2017). Although Croatian teachers generally support the inclusive process, teaching students with disabilities is a major challenge for which they are not fully prepared (Bouillet et al., 2017). Previous research consistently shows that teachers in Croatia do not have sufficient competencies to work with children with disabilities (Skočić Mihić et. al, 2014; Bouillet \& Bukvić, 2015; Domović, Vizek Vidović, Bouillet, 2017); however, they perceive themselves as moderately competent for the development, implementation and evaluation of IEP for students with disabilities, as well as for individualised instructions (Skočić Mihić, 2017).

Higher results in the Polish sample may be associated with their high satisfaction with work, which would be in line with the research by Wiśniewski (1990) and their generally posi- tive attitudes towards inclusion (Ćwirynkało and Żyta 2015; Ćwirynkało and Myśliwczyk 2016; Zuraw 2016). This is also in accordance with prior research conducted in Poland and Croatia by Ćwirynkało et al. (2017), which indicated that Polish elementary teachers received higher scores on two components of attitudes towards inclusion: affective (beliefs about the efficacy of inclusion) and cognitive (perceptions of students with mild to moderate disabilities).

In addition, possible explanation of the results could be the greater exposure of Croatian teachers to the challenges of inclusive education in comparison with Polish teachers. Research by the European Union on implementation of inclusive education for learners with disabilities (Soriano, Watkins and Ebersold, 2017, pg. 30-34) shows the differences between Croatia and Poland in the percentage of students with special education needs enrolled in regular schools. In Croatia, over $90 \%$ of children with disabilities attend regular mainstream schools, and less than $10 \%$ of children with special education needs and those with severe disabilities study in special schools; in Poland, less than $50 \%$ of students with special education needs participate in inclusive education settings, while the majority of students with special education needs are in special schools (Soriano et al., 2017). That places a lot of responsibility on Croatian teachers, especially when they do not have support from professional staff competent to deal with the challenges of teaching children with disabilities. Most children with intellectual disability, as well as children with ASD, attend regular classes in Croatia and meeting their needs could be a challenge for their teachers.

Another possible explanation is that teachers in Poland receive more support in complementation of inclusive education. Although teacher's assistants are employed almost exclusively when the class contains students with autism spectrum disorder, Asperger syndrome and multiple disabilities (Dudzińska and Niedźwiedzka 2018), educators in Poland usually do receive support from speech therapists, school pedagogues and special pedagogues. Many Croatian teachers from this sample and in general are not supported by special pedagogues or other specialised professionals or institutions, they must handle too many students in the 
class and they are dissatisfied with the way the inclusion is carried out (Kranjčec Mlinarić et al., 2016; Bouillet, 2013). These factors are reflected in their significantly lower assessment of school inclusiveness in the present study. On the other hand, teachers who have available professional support, positive school atmosphere and additional education, rate more highly the quality of inclusive school organisation, inclusive classroom approach and objective indicators of quality of inclusion (Wagner Jakab, Lisak and Cvitković, 2016). The importance of professional support to teachers in implementation of inclusive education has also been proven in recent Croatian studies (NikčevićMilković et al., 2019; Skočić Mihić, 2017).

Croatian teachers rated quality of inclusion more highly than Polish teachers only for Teaching assistant support. The Croatian educational system recommends that each school should provide teaching assistants in the classroom, interpreters of sign language or a personal assistant to students who, according to a decision on the appropriate form of education, need the necessary support in learning, moving and doing school activities and tasks (Official Gazette 63/2008 and 90/2010). Teachers and students point out the satisfaction with the support provided by the assistants (Krampač-Grljušić, Lisak and Žic Ralić, 2010; Krampač-Grljušić, Žic Ralić and Lisak, 2010). Nonetheless, taking into account some shortcomings, it seems that in Poland access to teaching assistants is more restricted. As highlighted before, they are rarely hired, usually in the case of integrative classes with 3-5 students with special education needs, or mainstream classes with children with autism spectrum disorder or a multiple disability. The vast majority of teachers who took part in the current study did not work with such assistants.

As far as the third research question (referring to the length of service) is concerned, the results of the current study suggest that in Croatia the best ratings on the subscale Differentiated learning and teaching came from the group of teachers with shorter work experience, and the lowest ratings from the group of participants with the longest experience. This result is in accordance with the finding of Skočić Mihić, Gabrić and Bošković (2016) that younger teachers, with higher level of education and less than 20 years of working experience, who have been exposed to at least one course on teaching in inclusive classes during their studies, are more convinced that inclusive education promotes inclusive values in the community and contributes to both academic and social development of both typically-developing students as well as those with disabilities. Older teachers, with lower level of education and more working experience, who were educated in traditional schools from which students with disabilities were excluded, recognise fewer advantages of modern inclusive education in comparison with younger colleagues.

Contrary to Croatia, in Poland the best ratings came from the group of teachers who had worked longer, while the lowest ratings came from the group with the shortest experience. In the case of the Polish sample, we suppose these results may be explained by teachers' experience working with students with various special education needs. Perhaps older teachers feel more confident, and their self-efficacy skills are higher. This is in line with prior research which indicates that older teachers had higher scores on the affective scale of beliefs about the efficacy of inclusion (Ćwirynkało et al. 2017) and suggests that teachers with more in-service inclusion experience are more prone to feel positively about inclusion (Jobb et al. 1996, Rakap, Kaczmerek, 2010).

Also, research carried out by Gajdzica (2012) about the opinions of Polish and Czech teachers on the changes in the education of students with intellectual disabilities, showed that Polish teachers with shorter work experience are more sceptical about inclusion solutions, especially in the case of students with moderate and severe intellectual disability.

On the contrary, other studies (e.g. Center et al. 1987, Vaz et al. 2015) suggest that older teachers hold more negative attitudes towards inclusion, which seems to be in line with the results of the Croatian sample. In this case the explanation may lie in generally more open, pro-inclusive attitudes of younger teachers in Croatia. We also think that it is possible that different results in the two countries may be the consequence of different systems of educating pre-service and in-service teachers in Poland and Croatia. In the case of Croatia, we 
suppose that younger teachers are more likely to be better trained in differentiated learning and teaching, since at the university level all teaching studies have at least one course about teaching children with disabilities. In Poland such courses are also obligatory, but it is also very common for in-service teachers to participate in various qualification courses (including post-graduate studies) that deal with special education. In Croatia older teachers also have a possibility to learn through lifelong learning, but such learning is not obligatory and there is no system to encourage teachers to acquire specific competences required for inclusive education (Batarelo Kokić et al. 2009).

\section{LIMITATIONS}

Several limitations to this study could be taken into consideration. First, the data were not collected in all the regions of the two countries, so there are limitations in making generalisations. Also, a relatively small sample size limits the interpretations. Moreover, in the assessment of quality of inclusion, only teachers' perspectives were taken into account. In order to investigate the quality of inclusion, the perspectives of other stakeholders (e.g. principals, parents, students) should be included. Finally, in order to gain a more comprehensive, in-depth view on the research subject, qualitative methods could be applied (e.g. interviews, observations) in further studies.

\section{CONCLUSION}

Both Polish and Croatian early education teachers gave positive subjective assessments of inclusion quality. Teachers from both countries gave the highest ratings of self-perceived competences regarding monitoring, giving instructions that are tailored to individual needs of their students, checking acquired knowledge and cooperation with par- ents. The lowest ratings were given on the subscale 'Teaching assistant support' by Polish participants and on the subscale 'Resources for inclusive education' by the Croatian sample. The comparison of Polish and Croatian teachers' assessments indicates that teachers from Poland rated their self-perceived competences for providing inclusive education as well as perceived inclusiveness on the school level higher than Croatian teachers. Croatian teachers gave a more positive assessment than Polish teachers about the quality of inclusion only with respect to teaching assistant support. The comparison of Polish and Croatian teachers' subjective assessments of inclusion quality in accordance with the length of service shows that less experienced teachers in Croatia and more experienced teachers in Poland have more positive assessments of their own competencies for assessing students' educational needs, student-oriented planning and applying different educational approaches than more experienced teachers in Croatia and less experienced teachers in Poland.

Based on these findings, the priorities for further development of quality inclusive education in both countries are improvement of support available to children with special education needs and to their teachers, as well as improvement of teachers' competences for inclusive education.

\section{ETHICAL CONSIDERATIONS}

The study was approved by the Ethical Committee at the Faculty of Social Sciences of the University of Warmia and Mazury in Olsztyn, Poland.

\section{DISCLOSURE STATEMENT}

No potential conflict of interest was reported by the authors 


\section{REFERENCES}

Adderley, R.J., Hope, M.A., Hughes, G.C., Jones, L. Messiou, K., Shaw P.A. (2015). Exploring inclusive practices in primary schools: focusing on children's voices. European Journal of Special Needs Education, 30(1), 106-121.

Ainscow, M. Booth T. \& A. Dyson (2006). Inclusion and the standards agenda: negotiating policy pressures in England. International Journal of Inclusive Education, 10(4-5), 295-308.

Barańska, M., Sirak, K. (2015). Poglądy osób związanych z oświatą na wspólne nauczanie dzieci o zróżnicowanych potrzebach edukacyjnych: Niepełnosprawność. Dyskursy Pedagogiki Specjalnej, 20, 128-142.

Bartnikowska, U., Ćwirynkało, K, Żyta, A. (2016). Nauczyciele szkoły integracyjnej wobec kształcenia dzieci z trudnościami emocjonalnymi i w zachowaniu. Niepełnosprawność. Dyskursy Pedagogiki Specjalnej, 23, 133-145.

Bąbka, J., Podgruszewska, M. (2016). Polityka oświatowa wobec uczniów ze specjalnymi potrzebami edukacyjnymi w perspektywie lokalnej- na podstawie opinii nauczycieli małego miasta. Niepełnosprawność. Dyskursy Pedagogiki Specjalnej, 22, 92-106.

Batarelo Kokić, I., Vukelić, A. and M. Ljubić (2009). Mapiranje politika i praksi za pripremu nastavnika za inkluzivno obrazovanje u kontekstima socijalne i kulturne raznolikosti, ["Maping policies and practices for preparing teachers for inclusive education in the contexts of social and cultural diversity"] Izvješće za Hrvatsku [Report for Croatia], Bologna, Italy: European Training Foundation. https://www.etf.europa.eu/sites/default/files/m/ E83FABD1CF05816EC12579C9003A8C74_NOTE85VD9Y.pdf

Bezinović, P. (ed.) (2010). Samovrednovanje škola: Prva iskustva u osnovnim školama. [School self-assessment: First experience in elementary schools] Zagreb: Agencija za odgoj i obrazovanje/Institut za društvena istraživanja u Zagrebu [Education and Teacher Training Agency/ Institute for Social Research in Zagreb]. https:/www.idi.hr/ cerd/uploads/DOKUMENTI/knjigePDF/Samovrednovanje_skola.pdf

Bidziński, K. (2014). Subiektywna ocena uzyskiwanego wsparcia zawodowego a nasilenie sytuacji trudnych odczuwanych przez nauczycieli podczas wykonywania zadań związanych z realizacją specjalnych potrzeb edukacyjnych uczniów. ["Subjective assessment of professional support and intensification of difficult situations experienced by teachers while performing tasks related to implementation of special educational needs of pupils"] Niepełnosprawność. Dyskursy Pedagogiki Specjalnej [Disability. Discourses of Special Education], 16, 106-125. https://niepelnosprawnosc.ug.edu.pl/index_en.html

Bidziński, K., Giermakowska, A., Ozga, A., and M. Rutkowski (2013). Nauczyciele województwa świętokrzyskiego wobec zadań związanych z realizacją specjalnych potrzeb edukacyjny uczniów. [Teachers of Świętokrzyskie Voivodeship towards tasks related to implementation of special educational needs of pupils] Kielce: Wydawnictwo Uniwersytetu Jana Kochanowskiego w Kielcach.

Booth, T., and M. Ainscow (2002). Index for Inclusion: developing learning and participation in schools. CSIE. London: Centre for Studies on Inclusion Education.

Bouillet, D. (2013). Some aspects of collaboration in inclusive education - teachers' experiences. CEPS Journal, $3(2), 93-117$.

Bouillet, D., Bukvić, Z. (2015). Razlike u mišljenjima studenata i zaposlenih učitelja o obrazovnoj inkluziji učenika s teškoćama. Hrvatska revija za rehabilitacijska istraživanja, 51(1), 9-23

Bouillet, D., Domović, V., Ivančević, S. (2017). Uvjerenja studenata učiteljskog studija i zaposlenih učitelja o inkluzivnoj praksi. Hrvatska revija za rehabilitacijska istraživanja, 53(2), 32-56.

Braunsteiner, M.L. \& Mariano-Lapidus, S. (2017). Using the Index for Inclusion to measure attitudes and perceptions of inclusion in teacher and school building leader candidates in the USA and Austria, International Journal of Inclusive Education, DOI: 10.1080/13603116.2017.1396503

Carter, E.W., Asmus, J., Moss, C.K., Biggs, E.E., Bolt, D.M., Born, T.L., Brock, M.E., et al. (2016). Randomized Evaluation of Peer Support Arrangements to Support the Inclusion of High School Students With Severe Disabilities. Exceptional Children 82(2), 209-233. 
Center,Y., Ward, J., Parmenter, T., and R. Nash (1985). Principals attitudes towards the integration of disabled children into regular schools. The Expectional Child, 32, 149-161.

Ciechanowski, J., Chmielewska B., Czyż E., and Z. Kołodziej (2010). Prawo do edukacji dzieci o specjalnych potrzebach edukacyjnych. Raport z monitoringu. [The right to educate children with special educational needs. Monitoring report] Warszawa: Helsińska Fundacja Praw Człowieka. http://www.hfhr.pl/wp-content/ uploads/2013/10/Monitoring_Prawo_do_edukacji_dzieci.pdf

Clench, H.K., and B., S., King (2015). Online training to promote inclusion: A systems level intervention. Educational \& Child Psychology 32(1), 62-70.

Ćwirynkało, K. (2013). Nauczyciele wobec zmian warunków kształcenia uczniów ze specjalnymi potrzebami edukacyjnymi (SPE). [Teachers towards changes in the conditions of education of students with special educational needs] In Chrzanowska, I, Jachimczak, B., Pawelczak, K. (editors): Miejsce innego we współczesnych naukach o wychowaniu. W poszukiwaniu pozytywów [The place of Other in modern education science. In search for positives], Poznań: Wydawnictwo Naukowe Uniwersytetu im. Adama Mickiewicza, 391-402.

Ćwirynkało K., Kisovar-Ivanda T., Gregory J., L., Żyta A., Arciszewska A., and S., Zrilić (2017). Attitudes of Croatian and Polish elementary school teachers towards inclusive education of children with disabilities. Croatian Review of Rehabilitation Research 53, Supplement, 252-264.

Ćwirynkało, K., and I. Myśliwczyk (2016). Mainstream School Teachers' Attitudes toward Inclusion of Children with Special Educational Needs in Poland. In: Titrek, O., I. Mikelsone, I., Pavitola, L., Sezen Gültekin, G. (ed.): ICLEL 2016 Conference Proceeding Book. 2nd International Conference on Lifelong Education and Leadership for All, Sakarya: Sakarya University, 680-687. https://www.iclel.com/iclel-16-publications

Ćwirynkało, K., and A., Żyta (2015). Przekonania nauczycieli na temat edukacji włączającej uczniów ze specjalnymi potrzebami. Raport z badań." [Teachers' beliefs concerning inclusive education for students with special needs. Research report] Szkoła Specjalna (Special School) 4, 245-259. http://www.szkolaspecjalna.aps.edu.pl/ media/785228/sz-s-4-15.pdf

Čepić, R., Tatalović Vorkapić, S., Lončarić, D., Anđić, D., Skočić Mihić, S., Kalin, J., \& Šteh, B. (2017). Profesionalni razvoj učitelja: status, ličnost i transverzalne kompetencije. Sažetci radova znanstveno-stručnog skupa Identitet i različitost u odgoju i obrazovanju, 21.- 23.09.2017 (p. 29). Zadar: Sveučilište u Zadru.

De Boer, A.; Pijl, S. J. \& Minnaert A. (2011). Regular primary schoolteachers' attitudes towards inclusive education: a review of the literature, International Journal of Inclusive Education, 15(3), 331-353, DOI: 10.1080/13603110903030089 (Special School) 4, 245-259. http://www.szkolaspecjalna.aps.edu.pl/media/785228/ sz-s-4-15.pdf

Domagała-Zyśk, E. (2018). Uczniowie z niepełnosprawnościami w szkołach ogólnodostępnych i integracyjnych w polskich badaniach naukowych. Warszawa: MEN.

Domović, V., Vizek Vidović, V. and D., Bouillet (2017). Student teachers' beliefs about the teacher's role in inclusive education. European Journal of Special Needs Education, 32(2), 175-190. http://dx.doi.org/10.1080/08856257. 2016.1194571

Drandić, D. (2017). Uloga pomoćnika u nastaviu provođenju inkluzivnoga obrazovanja [“The Role of Learning Support Teachers in Implementing Inclusive Education”]. Napredak: časopis za pedagogijsku teoriju i praksu, 158(4), 439-459. https://hrcak.srce.hr/188294

Dudzińska, A. and A., Niedźwiedzka (2018). Najczęstsze pytania dotyczące kształcenia specjalnego. Informator dla rodziców. [Most frequently asked questions about special education. A guide for parents] http://wszystkojasne. waw.pl/wp-content/uploads/2016/01/WszystkoJasne-Raport-Najcz\%C4\%99stsze-Pytania-Dotycz\%C4\%85ceKszta\%C5\%82cenia-Specjalnego.pdf

Ferguson, D. L. (2008). International trends in inclusive education: the continuing challenge to teach each one and everyone, European journal of special needs education, 23(2), 109-120, DOI: 10.1080/08856250801946236 
Anamarija Žic Ralić, Daniela Cvitković, Agnieszka Żyta, Katarzyna Ćwirynkało: The Quality of Inclusive Education From the Perspective of...

Forlin, C., Chambers, D., Loreman, T., Deppler, J., and U. Sharma (2013). Inclusive education for students with disability. A review of the best evidence in relation to theory and practice. Australia: Australian Research Alliance for Children and Youth.

https://www.aracy.org.au/publications-resources/command/download_file/id/246/filename/Inclusive_education_for_ students_with_disability_-_A_review_of_the_best_evidence_in_relation_to_theory_and_practice.pdf

Fernandez-Batanero, J.M., and M., El Homrani (2016). Effective teaching strategies to the educational exclusion. In Titrek, O., Potmesil, M., Vojtech, R., Zafer Güneş, D., Ekşioğlu, S., Sezen Gültekin, G. (ed.): ICLEL 2015 Proceeding Book. 1st International Conference on Lifelong Learning and Leadership for All, Sakarya: Sakarya University, 44-52. https://www.iclel.com/iclel-16-publications

Gajdzica, Z. (2012). Opinie polskich i czeskich nauczycieli na temat przemian kształcenia uczniów niepełnosprawnych intelektualnie. Część II. [“Opinions of Polish and Czech teachers about changes in education of students with intellectual disabilities"] Człowiek-Niepełnosprawność-Człowieczeństwo. (Man-Disability-Society) 2(16), 35-50. http://www.cns.aps.edu.pl/media/12665/cns_2_16_12.pdf

Gallagher P., Malone M. (2009). Social-Psychological Support Personnel: Attitudes and Perceptions of Teamwork Supporting Children With Disabilities. Journal of Social Work in Disability \& Rehabilitation, 8(1), 1-20.

Hick, P. (2005). Supporting the development of more inclusive practices using the index for inclusion. Educational Psychology in Practice, 21(2), 117-122.

Hornby, G. (2014). Inclusive Special Education. New York: Springer.

Ivančić, Đ. (2012). Pokazatelji kvalitete inkluzivne osnovne škole [“Indicators of Inclusive quality in primary school”]. Doctoral thesis. Zagreb: Faculty of Education and Rehabilitation Sciences, University of Zagreb. https://www. bib.irb.hr/pretraga/?q=Ivančić,+Đurđica+\%28203191\%29\&by=author

Jobb, D., Rust, J.O., and J., Brissie (1996). Teacher Attitudes Toward Inclusion of Students with Disabilities into Regular Classrooms. Education, 117(1), 148-153.

Krampač-Grljušić A., Lisak N., and A., Žic Ralić (2010). Što učitelji misle o ulozi asitenta u nastavi? ["What teachers think about the role of teaching assistants?"] Proceedings of the International Scientific and Professional Conference "Unapređenje kvalitete života djece i mladih" ["Improving the quality of life of children and youth"], 26 - 28 November, 2010, Tuzla, Bosnia and Herzegovina, 67-78. https://docuri.com/download/zbornik-konferencijadamir-za-cd-a_59c1d745f581710b28670a3a_pdf

Krampač-Grljušić, A., Žic Ralić, A., and N., Lisak (2010). Što djeca s teškoćama misle o podršci asistenta u nastavi ["What do children with difficulties say and think about their teacher assistant"], Proceedings "Uključivanje i podrška u zajednici" ("Inclusion and support within the community"), 8th Congress with International Participation of the Association of Defectologists in Croatia, Varaždin 22-24 April 2010, Croatia, 181-194. http://www.savezdefektologa.hr/wp-content/uploads/2014/09/zbornik2010.pdf

Kranjčec Mlinarić, J., Žic Ralić, A., and N., Lisak (2016). Promišljanje učitelja o izazovima i barijerama inkluzije učenika s poteškoćama u razvoju. ["Teachers' reflections on the challenges and barriers for integration of students with disabilities.”] Školski vjesnik, 65, 233-247. https://hrcak.srce.hr/160178

Lausselet, R. (2005): Prirucnik za samoevaluaciju. [Manual for self-evaluation] I. M. PACT, Lozana.

Kudek Mirošević, J., \& Jurčević Lozančić A. (2014). Stavovi odgojitelja i učitelja o provedbi inkluzije u redovitim predškolskim ustanovama i osnovnim školama. Hrvatska revija za rehabilitacijska istraživanja, 50(2), 17-29.

Lindsay, G. (2003): Inclusive education: A critical perspective. British Journal of Special Education, 30(1), 3-12.

Loreman, T. (2013). Measuring inclusive education outcomes in Alberta, Canada. International Journal of Inclusive Education, 18(5), 459-483.

Ljubić, M., Kiš - Glavaš, L. (2003). Razlike u stavovima nastavnika osnovnih i srednjih škola prema edukacijskoj integraciji, Hrvatska revija za rehabilitacijska istraživanja, 39(2), 129-136. 
Martan, V. (2018). Pregled istraživanja inkluzivnog odgoja i obrazovanja iz perspektive učitelja i studenata, Školski vjesnik, 67(2), 265-285.

Monsen, J.J., Ewing, D.L. \& Kwoka, M. (2014). Teachers' attitudes towards inclusion, perceived adequacy of support and classroom learning environment. Learning Environments Research, 17, 113-126 https://doi.org/10.1007/ s10984-013-9144-8

Nikčević-Milković, A., Jurković, D. and Durdov, J. (2019). Estimate of implementation of educational inclusion by primary school teachers and high school teachers, Croatian Journal of Education, 21(2), 599-638

Ostrowska, A. (2015). Niepełnosprawni w społeczeństwie 1993-2013 [The disabled in society 1993-2013], Wydawnictwo IFiS PAN, Warszawa.

Rakap, S., and L., Kaczmarek (2010). Teachers' attitudes towards inclusion in Turkey, European Journal of Special Needs Education, 25(1), 59- 75.

Ryan, T. G. (2009). Inclusive attitudes: A pre-service analysis. Journal of Research in Special Educational Needs, 9, $180-187$.

Saloviita, T., and T., Schaffus (2016). Teacher attitudes towards inclusive education in Finland and Brandenburg, Germany and the issue of extra work. European Journal of Special Needs Education, 31(4), 458-471.

Sánchez, S., Rodríguez, H., \& Sandoval, M. (2019). Descriptive and comparative analysis of School Inclusion through Index for Inclusion. Psychology, Society, \& Education, 11(1), 1-13.

Shogren, K. A., and M., L., Wehmeyer (2014). Using the Core Concept Framework to Understand Three Generation of Inclusive Practices. Inclusion, 2(3), 237-247

Skočić Mihić, S. (2011). Spremnost odgajatelja i faktori podrške za uspješno uključivanje djece s teškoćama u rani i predškolski odgoj i obrazovanje. ["The willingness of preschool teacher and support factors for the successful preschool inclusion of children with disabilities"] Doctoral thesis. Zagreb: Faculty of Education and Rehabilitation Sciences, University of Zagreb. https://www.bib.irb.hr/537386

Skočić Mihić, S. (2017). Učiteljska osposobljenost za izvedbu individualizirane nastave u inkuzivnim razredima. U: R. Čepić i J. Kalin (ur.): Profesionalni razvoj učitelja: status, ličnost i transverzalne kompetencije (str. 139-156), Rijeka: Učiteljski fakultet Sveučilišta u Rijeci.

Skočić Mihić, S., Gabrić, I., Bošković, S. (2016). Učiteljska uvjerenja o vrijednostima inkluzivnog obrazovanja. Hrvatska revija za rehabilitacijska istraživanja, 52(1), 30-41.

Skočić Mihić, S., Lončarić, D., Kolombo, M., Perger, S., Nastić, M., Trgovčić, E. (2014). Samoprocijenjene kompetencije studenata učiteljskog studija za rad s djecom s posebnim odgojno-obrazovnim potrebama. Napredak,154(3), 303-322.

Skotnicka, B.(2016). Gotowość nauczycieli do pracy z dzieckiem niepełnosprawnym (na przykładzie wybranego przedszkola ogólnodostępnego). Szkoła Specjalna, 2(283), 120-130.

Soriano, V., Watkins, A. and E., Ebersold (2017). Inclusive education for learners with disabilities. Study for the PETI Committee, Policy Department for Citizens' Rights and Constitutional Affairs, European Union.

Uberman, M., Mach, A. (2016). Kompetencje nauczyciela edukacji wczesnoszkolnej w szkole ogólnodostępnej w pracy z dzieckiem z niepełnosprawnością. Lubelski Rocznik Pedagogiczny, XXXV(3), 165-186.

UNESCO (1994). The Salamanca Statement and Framework for Action on Special Needs Education. World Conference on Special Needs Education, Access and Quality. Salamanca, Spain, 7-10 June 1994. Paris: UNESCO.

United Nations Human Rights (2016): Convention on the Rights of People with Disabilities. General comment No. 4 (2016) on the right to inclusive education. Geneva: United Nations Human Rights.

United Nations Human Rights (2017). United Nations Treaty Collection. Geneva: United Nations Human Rights.

Vaz, S., Wilson, N., Falkmer, M., Sim, A., Scott, M., Cordier, R., and T., Falkmer (2015). Factors Associated with Primary School Teachers'Attitudes Towards the Inclusion of Students with Disabilities. PLoS ONE, 10, 8, 1-12. 
Wagner Jakab, A., Lisak, N., Cvitković, D. (2016). Učiteljska procjena pokazatelja kvalitete inkluzije / Teachers assessment of indicators for inclusion. U: M. Potić, S. Golubović i Š. Šćepanović (ur.), Inclusive theory and practice international thematic collection of papers. (str. 39-50). Novi Sad: Društvo defektologa Vojvodine.

Winter, E., and P., O'Raw (2010). Literature Review of the Principles and Practices relating to Inclusive Education for Children with Special Educational Needs. ICEP Europe. Trim: The National Council for Special Education. http://ncse.ie/wp-content/uploads/2014/10/NCSE_Inclusion.pdf

Wiśniewski, W. (1990). The job satisfaction of teachers in Poland. Comparative Education, 26(2/3), 299-306.

Zeichner, K. M., \& Liston, D. P. (1987). Teaching student teachers to reflect. Harvard Educational Review, 57(1), 23-48

Žic Ralić, A. (2012). Inclusive education in Croatia. Proceedings of the International Scientific and Professional Conference "Inkluzivno obrazovanje - sostojba i predizvici" ["Inclusive education - situation and challenges"], Strumica, Macedonia: Union of Defectologists of the Republic of Macedonia, Ministry of Education and Science, Faculty of Philosophy - Institute for Defectology, 50-61. https://www.researchgate.net/publication/236121610 Inclusive_education_in_Croatia

Żuraw, H. (2016). Wizerunek dziecka z zaburzeniami rozwoju w poglądach nauczycieli szkół masowych. [The image of a child with developmental disorders in mainstream teachers' opinions] Lubelski Rocznik Pedagogiczny, 35(3), 75-106. 